Article

\title{
In Vitro Corrosion and Cell Response of Hydroxyapatite Coated Mg Matrix in Situ Composites for Biodegradable Material Applications
}

\author{
Nguyen Q. Cao ${ }^{1}\left(\right.$, Hai M. Le ${ }^{2, *}$, Khanh M. Pham ${ }^{2}$, Nam V. Nguyen ${ }^{3}$, Sachiko Hiromoto ${ }^{4}$ \\ and Equo Kobayashi ${ }^{5, *}$ \\ 1 PHENIKAA Institute for Advanced Study, PHENIKAA University, Hanoi 100000, Vietnam; \\ nguyen.caoquang@phenikaa-uni.edu.vn \\ 2 School of Materials Science and Engineering, Hanoi University of Science and Technology, \\ Hanoi 100000, Vietnam; khanh.phammai@hust.edu.vn \\ 3 Institute of Traumatology and Orthopaedics, 108 Military Central Hospital, Hanoi 100000, Vietnam; \\ namnguyenviet108@yahoo.de \\ 4 Corrosion Property Group, Research Center for Structural Materials, National Institute for Materials Science, \\ Tsukuba 305-0047, Japan; hiromoto.sachiko@nims.go.jp \\ 5 Department of Materials Science and Engineering, Tokyo Institute of Technology, Tokyo 152-8550, Japan \\ * $\quad$ Correspondence: hai.leminh@hust.edu.vn (H.M.L.); equo@mtl.titech.ac.jp (E.K.); Tel.: +81-3-5734-3147 (E.K.)
}

Received: 23 September 2019; Accepted: 18 October 2019; Published: 23 October 2019

check for updates

\begin{abstract}
In this study, hydroxyapatite (HAp) coated Mg matrix composites were fabricated for biodegradable implant applications. Spark plasma sintering was employed to fabricate the $\mathrm{Mg}-10$ $\mathrm{wt} \% \mathrm{ZnO}$ composite substrates. HAp was coated on the surface of the sintered composites and pure $\mathrm{Mg}$ by a chemical solution treatment. SEM and optical micrographs of coated samples showed that HAp grew homogeneously and formed a layer on the entire surface of both pure sintered $\mathrm{Mg}$ and $\mathrm{Mg}$ composites. The immersion and polarization test results demonstrated that the HAp coating significantly improved the corrosion resistance of the sintered composites. While the HAp coating layer is not effective in the improvement of the pure $\mathrm{Mg}$ substrate, cell culture test results revealed that the HAp coating improved cell adhesion and proliferation on the composites effectively through $72 \mathrm{~h}$, while no cell could survive on the uncoated composites after $72 \mathrm{~h}$. In addition, the corrosion tests and cell culture test results indicated that the composite with longer sintering time has better corrosion resistance and cell viability than those of the composite with shorter sintering time. The findings suggested that the HAp-coated Mg-10 $\mathrm{wt}_{\mathrm{H}} \mathrm{ZnO}-2.5 \mathrm{~h}+10 \mathrm{~min}$ composite is a high-potential candidate for biodegradable implant applications.
\end{abstract}

Keywords: hydroxyapatite; Mg matrix composite; coating; corrosion resistance; cell viability

\section{Introduction}

$\mathrm{Mg}$ and $\mathrm{Mg}$ alloys are considered as high-potential materials for biodegradable implant applications [1-3]. Magnesium materials possess two major advantages for biodegradable implant applications: no need for secondary surgery after bone healing and avoiding stress shielding effect, for their equivalent Young's modulus to bone [1-4]. In addition, $\mathrm{Mg}$ and $\mathrm{Mg}$ alloys are expected to be biocompatible because $\mathrm{Mg}$ is an essential element in the human body [5]. However, the main drawbacks of $\mathrm{Mg}$ and $\mathrm{Mg}$ alloys are their rapid corrosion rate, resulting in the deterioration of mechanical properties before bone healing and the formation of a gas cavity [6,7]. To solve this problem, the design and fabrication of new $\mathrm{Mg}$ matrix composites are a prospective approach. 
Dubey et al. fabricated Mg-3Zn-5HAp composite for biomedical applications [8]. The results suggested that the mechanical integrity of the fabricated Mg-3Zn-5HAp composite has been improved significantly compared to that of Mg-3Zn alloy after immersion tests for 3, 7, and 14 days in simulated body fluid. Witte et al. fabricated Mg matrix composite from AZ91 alloy and HAp as a biomaterial. The results demonstrated that HA effectively reinforced the mechanical properties and improved corrosion resistance of the fabricated composite compared to those of the AZ91 alloy [9]. Narita et al. fabricated $\mathrm{Mg} / \beta-\mathrm{TCP}$ composites via the spark plasma sintering method for biodegradable material applications [10]. The findings indicated that the in vitro corrosion resistance and cytocompatibility of the fabricated $\mathrm{Mg} / \beta$-TCP composites have been enhanced effectively compared to those of pure $\mathrm{Mg}$. In our previous studies [11,12], $\mathrm{Mg}$-ZnO in situ composites were fabricated successfully via spark plasma sintering (SPS) technique. With the reinforcement of in situ reaction products, including MgO, $\mathrm{Zn}$, and intermetallic compounds, the fabricated composites showed superior mechanical properties to pure $\mathrm{Mg}$ and cast $\mathrm{Mg}$ alloys and improved the corrosion resistance for biodegradable material applications. In this study, aiming to further improve the corrosion resistance and cell viability of the fabricated $\mathrm{Mg}-\mathrm{ZnO}$ in situ composites, surface coating was carried out on the composite substrates.

Surface coating is an effective method for improving the corrosion resistance of $\mathrm{Mg}$ materials [13-18]. The selection of an appropriate coating material is important because the coating material should be biocompatible. Among various coating materials, hydroxyapatite (HAp) is an effective coating material to improve both corrosion resistance and biocompatibility of Mg alloys [13-18]. Because HAp is the main component of human bone, it enhances the precipitation of calcium phosphate compounds on the surface from the simulated body fluids during biodegradation, which improved the corrosion resistance of $\mathrm{Mg}[19,20]$. However, HAp coating on $\mathrm{Mg}$ matrix composites has not been investigated so far. In this study, HAp coating was conducted on the surface of the Mg matrix in situ composite substrates. The effect of the HAp coating layer on the corrosion behavior and the cell viability on the composites was examined. The uncoated samples were studied and reported in our previous work [12] and are not a part of this research.

\section{Material and Methods}

\subsection{Composite Synthesis}

$\mathrm{Mg}$ powders with a purity of $99.5 \%$ and particle size of $180 \mu \mathrm{m}$ and $\mathrm{ZnO}$ powders with a purity of $99.9 \%$ and particle size of $1 \mu \mathrm{m}$ supplied by the KOJUNDO CHEMICAL LABORATORY CO., LTD-Japan were used for $\mathrm{Mg}$ matrix in situ composite syntheses. $\mathrm{Mg}-10 \mathrm{wt} \% \mathrm{ZnO}$ was mixed homogeneously with zirconia balls ( 2.5 of ball to powder weight ratio) in an argon atmosphere using a planetary micro ball mill (Pulverisette 7, Fritsch, Idar, Oberstein, Germany) with a rotation speed of $500 \mathrm{rpm}$ for $12 \mathrm{~h}$. The mixed powders were set inside a tungsten-carbide die, $120 \mathrm{~mm}$ in height and $15 \mathrm{~mm}$ in inner diameter. The powder was compacted under $10 \mathrm{MPa}$ for $1 \mathrm{~min}$ to form green compacts. The green compacts were then used for composite synthesis.

There were two types of composites fabricated. Mg-10ZnO-10 min was the composite sintered directly from the green compact by SPS (SPS-511S, Syntec Inc., Kanagawa, Japan) for $10 \mathrm{~min}$, and $\mathrm{Mg}-10 \mathrm{ZnO}-2.5 \mathrm{~h}+10 \mathrm{~min}$ was the composite sintered by two steps from the green compact. The first step was the sintering in a vacuum for $2.5 \mathrm{~h}$ without pressure [11,12]. The second step was the sintering by SPS for $10 \mathrm{~min}$. In addition, pure Mg powder was also sintered by SPS for $10 \mathrm{~min}$ for comparison. The details of the fabrication process and sample names are shown in Table 1. All the sintering processes were performed in a vacuum furnace. After sintering processes, the samples were cooled to room temperature inside the vacuum furnace. 
Table 1. Name, composition, and synthesis conditions of the samples.

\begin{tabular}{cccc}
\hline Sample Name & Composition & $\begin{array}{c}\text { Sintering in a Vacuum } \\
\left(\mathbf{T}=\mathbf{5 5 0} \mathbf{}^{\circ} \mathbf{C}, \mathbf{P}=\mathbf{0} \mathbf{M P a}\right)\end{array}$ & $\begin{array}{c}\text { Sintering by SPS } \\
\left(\mathbf{T}=\mathbf{5 5 0} \mathbf{~} \mathbf{~}^{\mathbf{P}} \mathbf{=} \mathbf{5 0} \mathbf{M P a}\right)\end{array}$ \\
\hline $\mathrm{Mg}$ & Pure Mg powder & 0 & $10 \mathrm{~min}$ \\
\hline $\mathrm{Mg}-10 \mathrm{ZnO}-10 \mathrm{~min}$ & $\mathrm{Mg}-10 \mathrm{mass} \% \mathrm{ZnO}$ & 0 & $10 \mathrm{~min}$ \\
\hline $\mathrm{Mg}-10 \mathrm{ZnO}-2.5 \mathrm{~h}+10 \mathrm{~min}$ & $\mathrm{Mg}-10 \mathrm{mass} \% \mathrm{ZnO}$ & $2.5 \mathrm{~h}$ & $10 \mathrm{~min}$ \\
\hline
\end{tabular}

\subsection{HAp Coating}

The sintered composites were machined into a disc shape with a size of $\Phi 15 \times t 2(\mathrm{~mm})$. The machined samples were ground using SiC papers up to 4000 grit, ultrasonically cleaned with ethanol, and then dried in air. Treatment solution for HAp coatings was prepared from ethylenediaminetetraacetic acid calcium disodium salt hydrate $\left(\mathrm{C}_{10} \mathrm{H}_{12} \mathrm{CaN}_{2} \mathrm{Na}_{2} \mathrm{O}_{8}\right.$, Ca-EDTA) solution with the concentration of $0.5 \mathrm{~mol} / \mathrm{L}$ and potassium dihydrogen phosphate $\left(\mathrm{KH}_{2} \mathrm{PO}_{4}\right)$ solution with the concentration of $0.5 \mathrm{~mol} / \mathrm{L}$, and sodium hydroxide $(\mathrm{NaOH})$ solution was used for $\mathrm{pH}$ adjustment. The $\mathrm{pH}$ of the treatment solution was adjusted to 7.5. The discs were immersed in the treatment solution at $90^{\circ} \mathrm{C}$ for $2 \mathrm{~h}$ for HAp coating.

The coated samples were then characterized by X-ray diffractometry (XRD) (RINT2100, Rigaku, Tokyo, Japan) and scanning electron microscope (SEM) (Miniscope TM3000, Hitachi, Tokyo, Japan) to evaluate the growth of HAp coating layer.

\subsection{Immersion Test}

The HAp-coated samples were immersed in Hanks' solution at $37^{\circ} \mathrm{C}$ for 14 days to evaluate the corrosion properties. The composition of the Hanks' solution is described in Table 2. The ratio of surface area to solution volume was $1 \mathrm{~cm}^{2}: 50 \mathrm{~mL}$. The immersion tests were conducted in triplicate for each sample condition.

Table 2. Composition of Hanks' solution used for immersion tests.

\begin{tabular}{cccccccc}
\hline Reagent & $\mathbf{N a C l}$ & $\mathrm{KCl}$ & $\mathrm{Na}_{2} \mathbf{H P O}_{4} \cdot \mathbf{H}_{\mathbf{2}} \mathbf{O}$ & $\mathbf{K H}_{2} \mathbf{P O}_{4}$ & $\mathbf{M g S O}_{4} . \mathbf{7 H _ { 2 }} \mathbf{O}$ & $\mathbf{N a H C O}_{3}$ & $\mathbf{C a C l}_{\mathbf{2}}$ \\
\hline $\begin{array}{c}\text { Concentration } \\
(\mathrm{g} / \mathrm{L})\end{array}$ & 8 & 0.4 & 0.06 & 0.06 & 0.2 & 0.35 & 0.14 \\
\hline
\end{tabular}

The amount of $\mathrm{Mg}^{2+}$ ions dissolved in the solution was quantified by a colorimetric method using Xylidyl blue-I [21,22]. In addition, hydrogen gas generated was collected by a burette with a funnel that was placed over the immersed sample. After 14 days of immersion, the immersed samples were retrieved from the solution for the surface characterization by SEM and energy dispersive X-ray spectrometer (EDS) (Quantax 70, Bruker, Billerica, MA, USA).

\subsection{Polarization Tests}

Polarization tests were carried out in Hanks' solution. The surface was coated with epoxy resin to expose the measurement area of $1 \mathrm{~cm}^{2}$ to Hanks' solution at $37^{\circ} \mathrm{C}$. The open circuit potential was measured for $1500 \mathrm{~s}$. Subsequently, potentiodynamic polarization curves were measured in the potential range from $-0.1 \mathrm{~V}$ vs. open circuit potential $\left(E_{\mathrm{ocp}}\right)$ at a scan rate of $1 \mathrm{mV} / \mathrm{s}$. A reference and counter electrode were saturated $\mathrm{Ag} / \mathrm{AgCl}$ and Pt electrodes, respectively.

\subsection{Cell Viability Test}

The HAp-coated and uncoated samples were then used for the evaluation of cell viability by cell culture tests. The cell culture tests were carried out using mouse osteoblastic cell line MC3T3-E1 supplied by RIKEN Cell Bank (Cell No. RBRC-RCB1126) in $\alpha$ medium supplemented with 10 vol.\% 
fetal bovine serum $(\alpha-\mathrm{MEM}+\mathrm{FBS})$ at $37 \pm 0.5{ }^{\circ} \mathrm{C}$ under a $5 \% \mathrm{CO}_{2}$ atmosphere for 24,48 , and $72 \mathrm{~h}$, respectively. The initial cell density in cell culture tests was 25,000 cells $/ \mathrm{cm}^{2}$.

After incubation for 24,48 , and $72 \mathrm{~h}$, the samples were retrieved from the medium, and the cells were stained with Giemsa for observation of cell proliferation and morphology. In this study, the cell viability was examined qualitatively; therefore, the Giemsa stain method was used for its low cost and simplicity.

\section{Result and Discussion}

\subsection{Composition and Microstructure of Sintered Composites}

XRD patterns of the sintered $\mathrm{Mg}$, Mg-10ZnO-10 min, and $\mathrm{Mg}-10 \mathrm{ZnO}-2.5 \mathrm{~h}+10 \mathrm{~min}$ samples are shown in Figure 1. There are only peaks of $\mathrm{Mg}$ on the XRD pattern of sintered pure $\mathrm{Mg}$, while peaks of $\mathrm{MgO}$ appeared additionally to the peaks of $\mathrm{Mg}$ on the XRD patterns of the composites. The authors [11,12] demonstrated that the following in situ reactions occurred during sintering mixed $\mathrm{Mg}$ and $\mathrm{ZnO}$ powders from $450^{\circ} \mathrm{C}$ to $550^{\circ} \mathrm{C}$.

$$
\begin{gathered}
\mathrm{Mg}_{(\mathrm{s})}+\mathrm{ZnO}_{(\mathrm{s})} \stackrel{450-500{ }^{\circ} \mathrm{C}}{\longrightarrow} \mathrm{MgO}_{(\mathrm{s})}+\mathrm{Zn}_{(1)}, \\
\mathrm{Mg}_{(\mathrm{s})}+\mathrm{Zn}_{(\mathrm{l})} \stackrel{500-550^{\circ} \mathrm{C}}{\longrightarrow} \mathrm{Mg}-\mathrm{Zn}_{(1)}, \\
\mathrm{Mg}-\mathrm{Zn}_{(\mathrm{l})} \stackrel{\text { Cooling }}{\longrightarrow} \mathrm{Mg}_{(\mathrm{s})}+\mathrm{Mg}_{\mathrm{x}} \mathrm{Zn}_{\mathrm{y}},
\end{gathered}
$$

where the subscripts (s) and (l) refer to solid state and liquid state, respectively, and $\mathrm{Mg}_{\mathrm{x}} \mathrm{Zn}_{\mathrm{y}}$ corresponds to $\mathrm{MgZn}, \mathrm{Mg}_{2} \mathrm{Zn}_{3}$, and $\mathrm{Mg}_{7} \mathrm{Zn}_{3}$ intermetallic compounds.

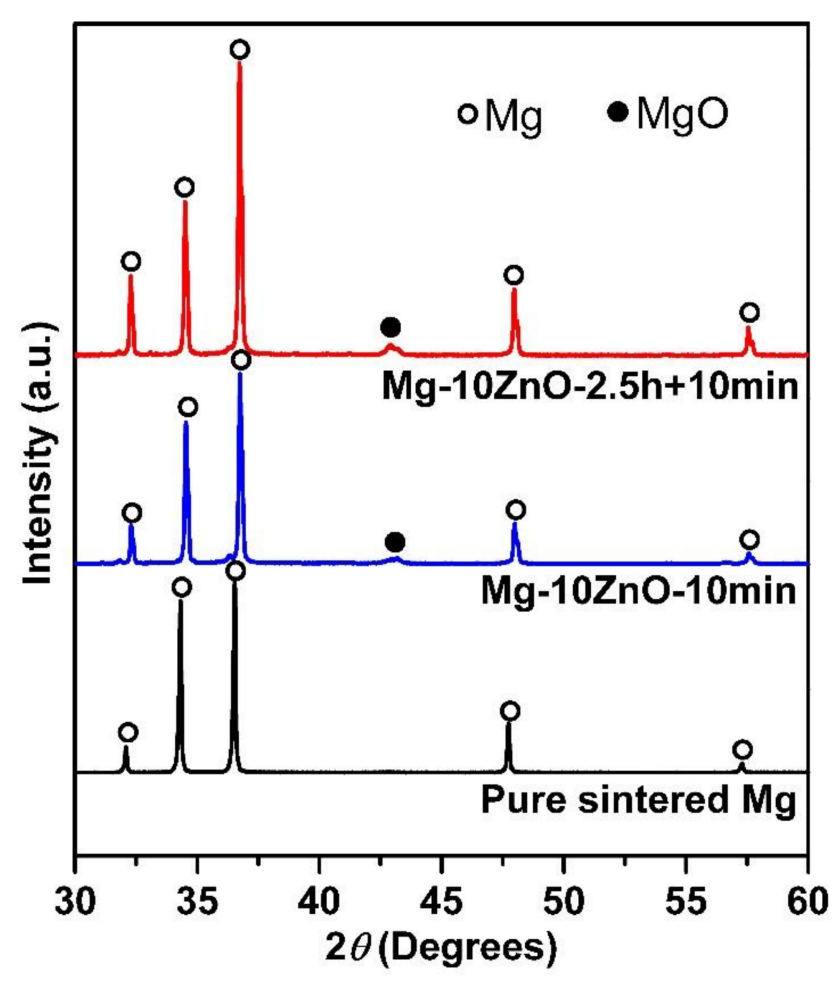

Figure 1. XRD patterns of sintered samples.

The in situ reaction (1) explains the existence of $\mathrm{MgO}$ as an in situ reaction product. Therefore, the peaks of $\mathrm{MgO}$ appeared on the XRD patterns of the sintered composites. Based on the Mg-Zn binary phase diagram [23], the reactions (2) and (3) occurred reasonably. Therefore, $\mathrm{Zn}$ and $\mathrm{Mg}$ - Zn intermetallic 
compounds were formed as a part of in situ reaction products in the sintered composites [11,12]. The amount of newly formed $\mathrm{MgO}, \mathrm{Zn}$, and intermetallic compounds in the $\mathrm{Mg}-10 \mathrm{ZnO}-10 \mathrm{~min}$ and Mg-10ZnO-2.5 h + 10 min composites are different due to different sintering time [12].

Figure 2 shows the SEM micrographs of the sintered composites with different magnifications. Figure $2 \mathrm{a}, \mathrm{b}$ show that both composites have two identical phases of $\mathrm{Mg}$ matrix and dispersion of reinforcement. The reinforcement phase contained randomly dispersed white particles which were remained $\mathrm{ZnO}$ [12]. The amount of remained $\mathrm{ZnO}$ in the $\mathrm{Mg}-10 \mathrm{ZnO}-10$ min sample was much higher than in the Mg-10ZnO-2.5 h +10 min sample, as shown in Figure 2c,d because the sintering time of the former was only 10 min which was remarkably shorter than the total sintering time of 160 min of the latter. The in situ reactions (1) and (2) progressed further with an increase in sintering time. Therefore, the amount of remained $\mathrm{ZnO}$ in the single-step composite became larger than that in the double-step composites. The smaller amount of remained $\mathrm{ZnO}$ corresponded to the progress of the reactions (1) and (2). This fact indicates that the amount of produced $\mathrm{MgO}$ and intermetallic compounds in the double-step composites was larger than those in the single-step sintering composite [12].
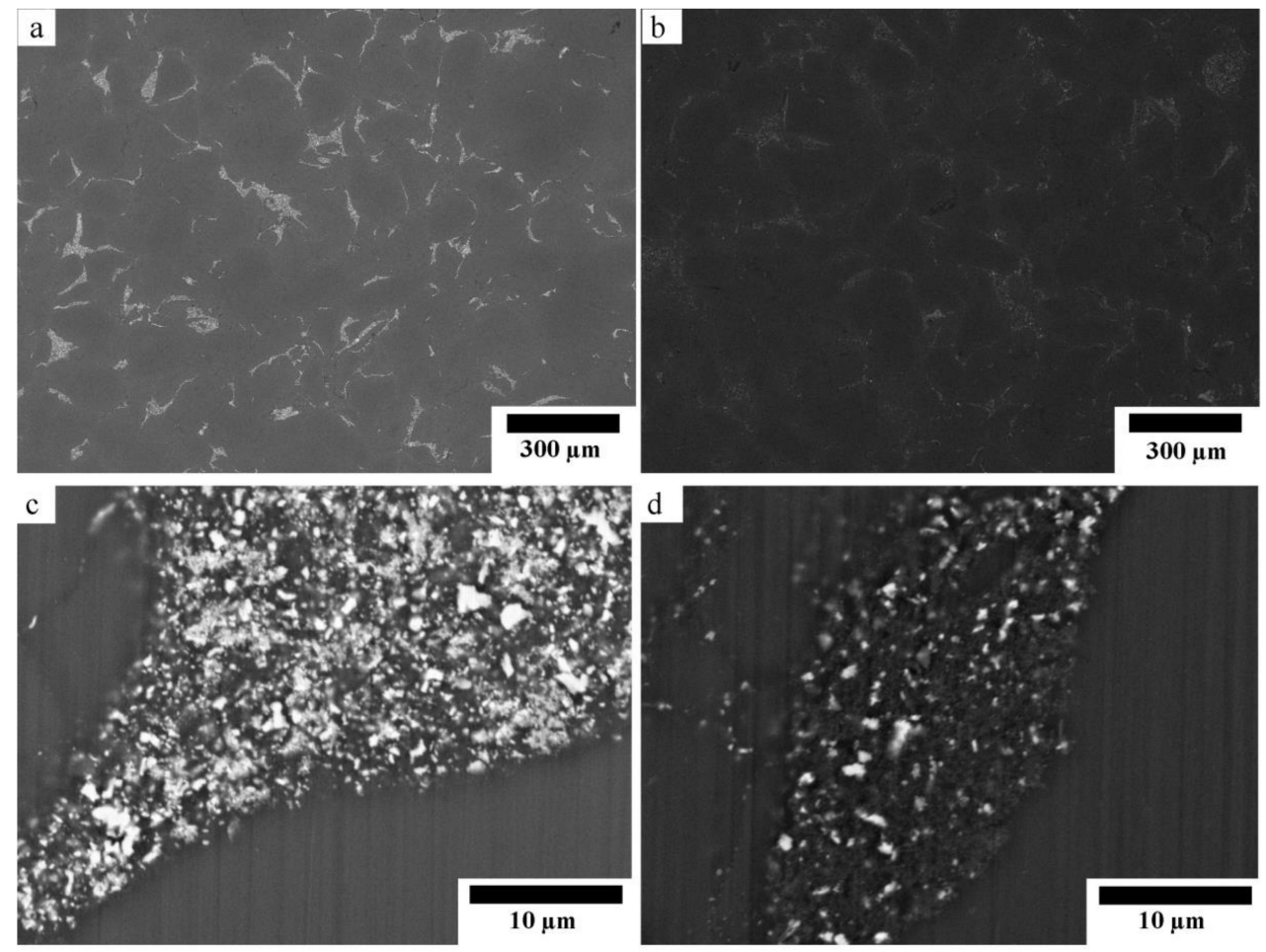

Figure 2. SEM micrographs of the sintered composites: (a,c) Mg-10ZnO-10 min, (b,d) Mg-10ZnO-2.5 h $+10 \mathrm{~min}$.

\subsection{HAp Growth on Surface of Sintered Samples}

Figure 3 shows XRD patterns of HAp-coated Mg, Mg-10ZnO-10 min, and Mg-10ZnO-2.5 h + 10 min samples. All samples show high intensity peaks of HAp. This demonstrated that HAp grew successfully on the surface of all samples. On all substrates, the (002) HAp peak showed a higher intensity than the other HAp peaks. This suggested that the (002) plane of HAp grew preferentially. This preferential orientation of the (002) plane of HAp to the surface is similar to that of HAp on Mg alloys in previous studies [13,17].

Figure 4 shows the SEM micrographs of HAp-coated Mg, Mg-10ZnO-10 min, and Mg-10ZnO-2.5 h +10 min samples with different magnifications. All surfaces were covered with HAp layers with an outside porous structure consisting of rod-like crystals. Because the morphology of the outside surface of the HAp coatings in this study was similar to that formed on pure Mg and AZ31 [13,17], the HAp layers in this study necessarily had a continuous inner layer, which shows corrosion protection 
ability. On pure $\mathrm{Mg}$, cracking of the HAp layer was observed probably along the grain boundaries in Figure 4a. On Mg-10ZnO-2.5 h + $10 \mathrm{~min}$, flower-like agglomerates randomly appeared on the top surface. The flower-like HAp agglomerates presumably nucleated from $\mathrm{MgO}$ and $\mathrm{MgZn}$ intermetallic compounds rich regions on this sample.

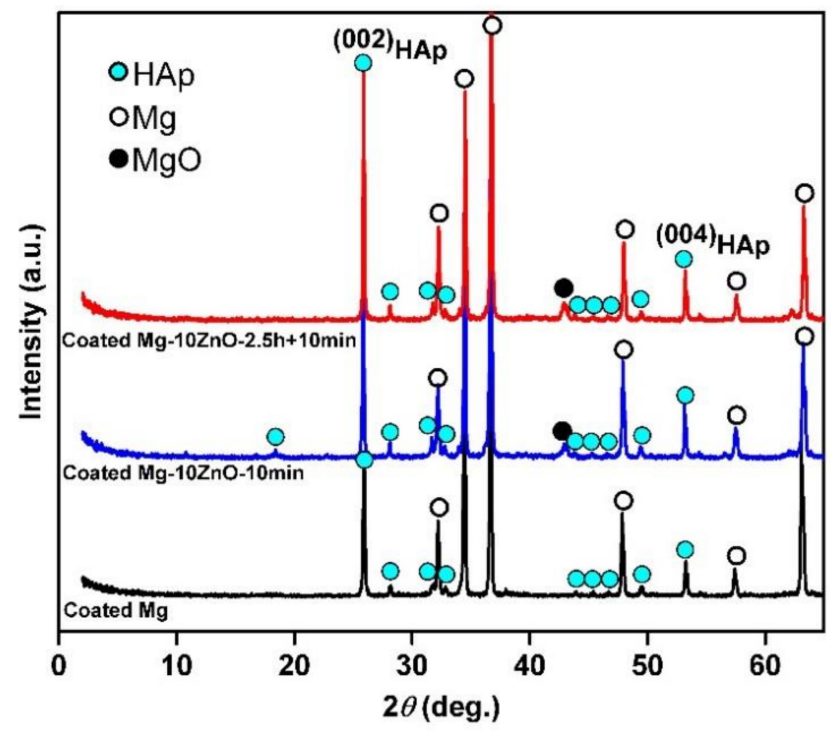

Figure 3. XRD patterns of hydroxyapatite (HAp)-coated samples.
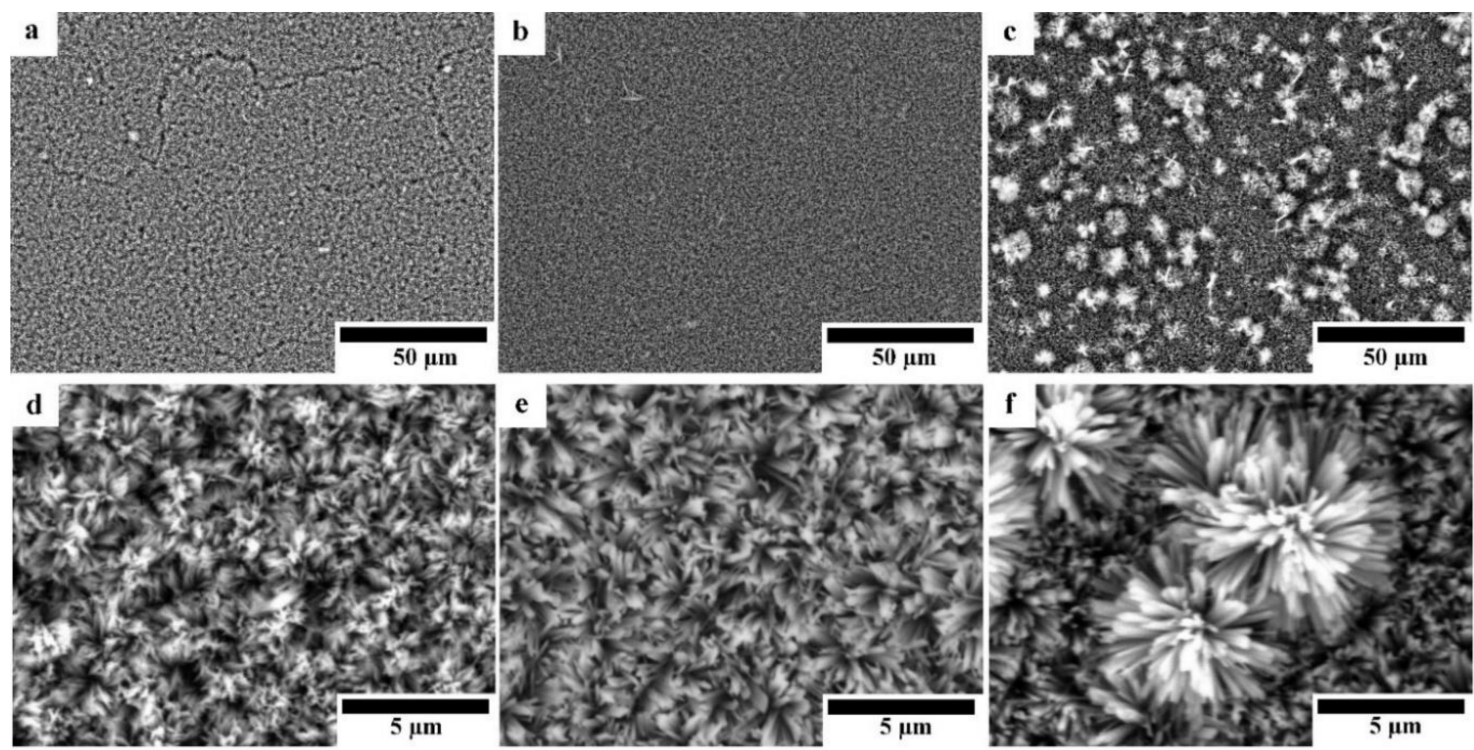

Figure 4. SEM micrographs of HAp-coated samples: (a,d) HAp-coated Mg, (b,e) HAp-coated Mg-10ZnO-10 min, (c,f) HAp-coated Mg-10ZnO-2.5 h + 10 min.

Optical micrographs of coated samples are shown in Figure 5. As shown in Figure 5a,d, the HAp layer grows homogeneously on the surface of $\mathrm{Mg}$ substrate; while the grain boundaries between $\mathrm{Mg}$ particles are observed through the HAp layer, indicating that HAp layer on the Mg substrate was transparent and the grain boundaries were preferentially corroded in the HAp coating solution. No grain boundary was observed through the HAp layer on the surface of HAp-coated composites; however, the grey grains of the second phase are observed through the transparent HAp layer. This appearance indicates that the second phase was preferentially corroded in the HAp coating solution due to the existence of $\mathrm{MgO}$ and intermetallic compounds. The macroscopically uniform 
coating shown in Figure 5a,b indicates that the apparent micro galvanic corrosion in the HAp coating solution did not influence the macroscopic morphological uniformity of the HAp layer on $\mathrm{Mg}$ and Mg-10ZnO-10 min samples. The HAp-coated Mg-10ZnO-2.5 h + 10 min shows the uniform coating layer with randomly distributed white agglomerates. These white agglomerates corresponded to flower-like crystals on the SEM images in Figure 4c,f. The grains of the second phase were preferentially corroded on $\mathrm{Mg}-10 \mathrm{ZnO}-2.5 \mathrm{~h}+10 \mathrm{~min}$ as well as those on $\mathrm{Mg}-10 \mathrm{ZnO}-10 \mathrm{~min}$; however, the distribution of white agglomerates was macroscopically inconsistent to that of the corroded second phase. Although the formation of HAp crystal agglomerates was observed, the composite surface was completely covered with the HAp layer.
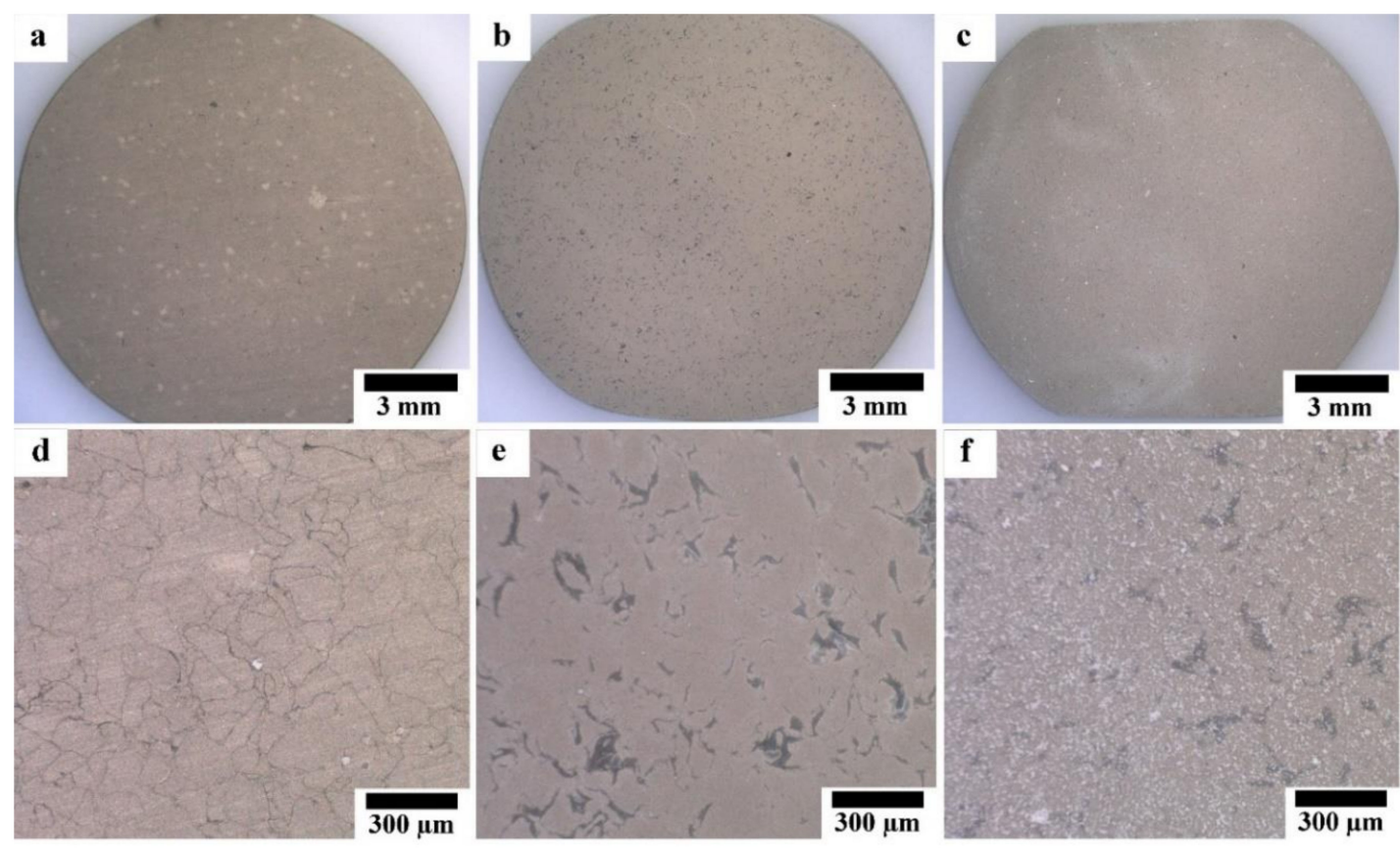

Figure 5. Optical micrographs of HAp-coated samples: (a,d) HAp-coated Mg, (b,e) HAp-coated Mg-10ZnO-10 min, (c,f) HAp-coated Mg-10ZnO-2.5 h + 10 min.

\subsection{Static Corrosion Behavior in Hanks' Solution}

Figure 6a shows the amount of $\mathrm{Mg}^{2+}$ ion released per $\mathrm{cm}^{2}$ as a function of the immersion period of HAp-coated in Hanks' solution. The coated Mg-10ZnO-2.5 h $+10 \mathrm{~min}$ samples showed the lowest corrosion rate, while the coated $\mathrm{Mg}$ exhibited the highest amount of $\mathrm{Mg}^{2+}$ ion released within the coated samples. This indicates that the corrosion resistance of HAp-coated composites was dominated by the corrosion resistance of the substrate composite because $\mathrm{Mg}-10 \mathrm{ZnO}-2.5 \mathrm{~h}+10 \mathrm{~min}$ substrate had the highest corrosion resistance as shown in Figure 6b referred from [12].

Figure 7a shows the hydrogen-evolution behavior of HAp-coated samples during 14 days-immersion in Hanks' solution. The hydrogen-evolution behavior showed the same order of corrosion resistance between samples to the $\mathrm{Mg}^{2+}$ ion release behavior. Specifically, the coated $\mathrm{Mg}-10 \mathrm{ZnO}-2.5 \mathrm{~h}+10 \mathrm{~min}$ samples showed the smallest amount of hydrogen gas release while the coated $\mathrm{Mg}$ exhibited the largest amount of hydrogen gas release. This result confirms that the HAp-coated Mg-10ZnO-2.5 $\mathrm{h}+$ 10 min samples showed the lowest corrosion rate, while the HAp-coated pure Mg showed the highest corrosion rate.

Figure 8 shows optical micrographs of the HAp-coated Mg-10ZnO-10 min and Mg-10ZnO-2.5 h + 10 min samples immersed in Hanks' solution for 14 days. The coated pure $\mathrm{Mg}$ samples were fractured during the immersion test due to the poor corrosion resistance of this sample. The coated Mg-10ZnO-10 min showed many severe localized corrosion sites and a significant amount of corrosion product deposited, while the coated $\mathrm{Mg}-10 \mathrm{ZnO}-2.5 \mathrm{~h}+10 \mathrm{~min}$ sample showed a few localized corrosion 
sites. This result indicates that the coated $\mathrm{Mg}-10 \mathrm{ZnO}-10 \mathrm{~min}$ had many corrosion initiation sites like defects of the coating and/or the inhomogeneous sites of the substrate composite. The corrosion progress led to the increase in corrosion product, which caused the breakage and delamination of the HAp coating. A smaller number of corrosion sites of the coated Mg-10ZnO-2.5 $\mathrm{h}+10 \mathrm{~min}$ samples indicates that the corrosion initiation sites decreased by the long time sintering.

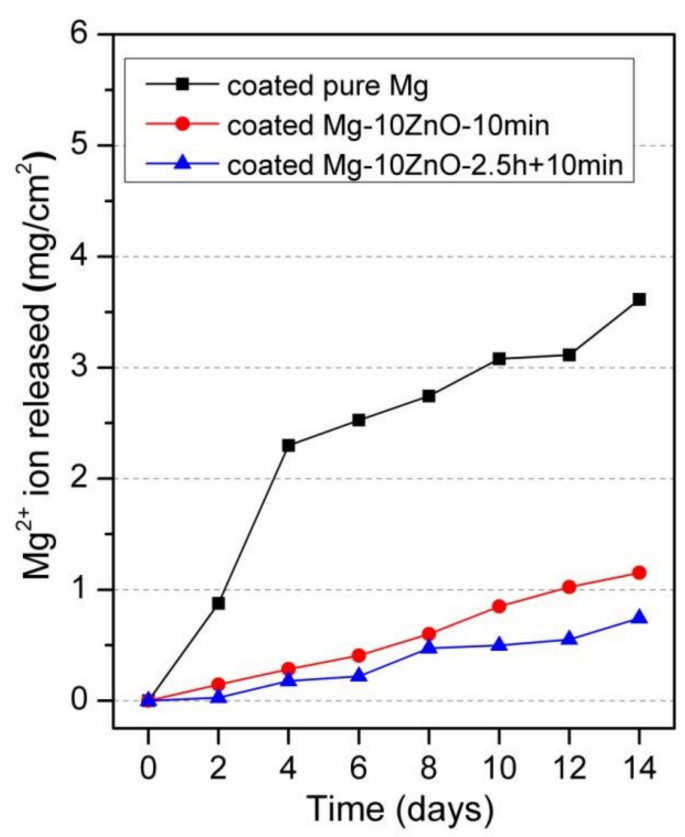

(a)

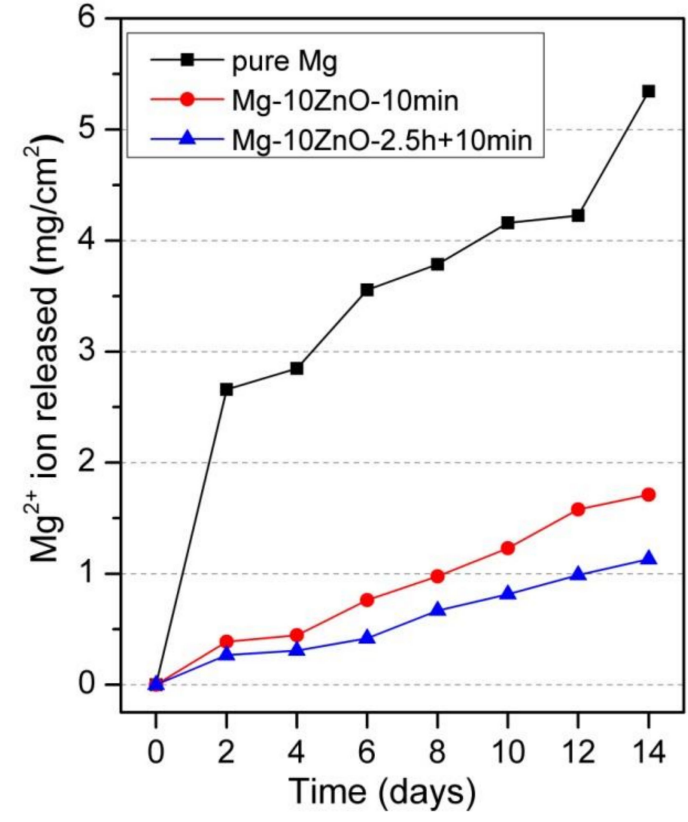

(b)

Figure 6. $\mathrm{Mg}^{2+}$ ion release in Hanks' solution during immersion test, (a) the result of HAp coated samples in this study, and (b) the result of uncoated samples was cited from [12].

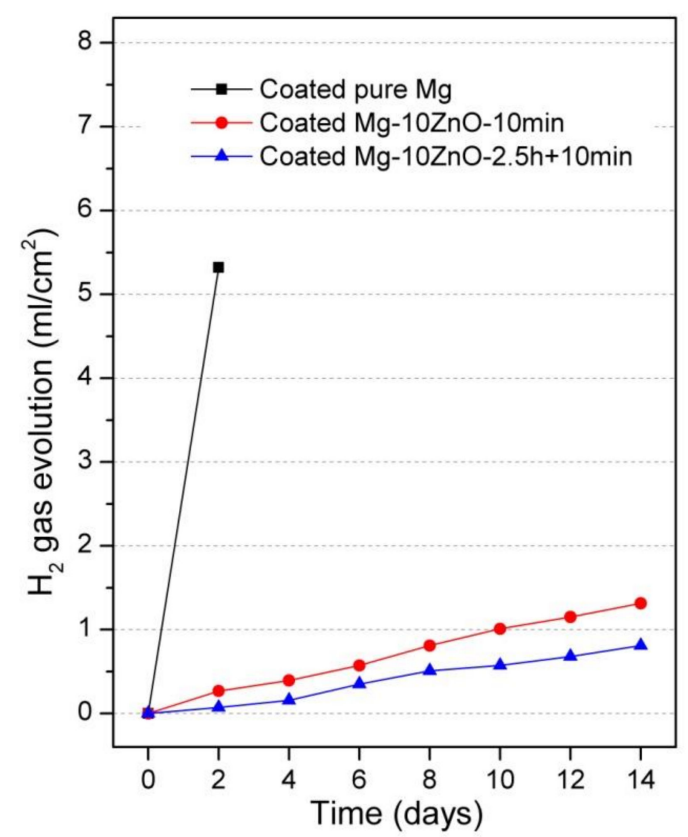

(a)

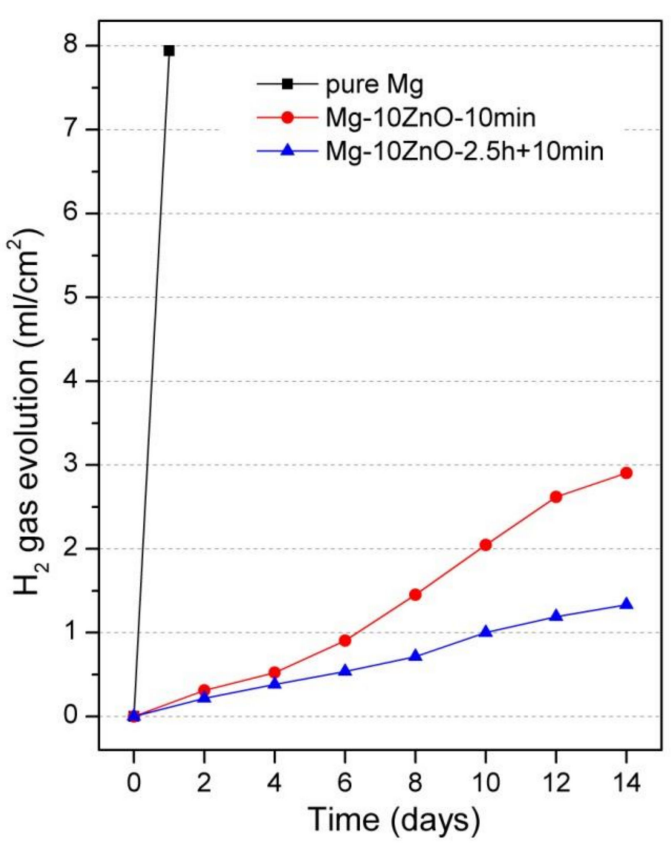

(b)

Figure 7. Hydrogen gas evolution during the immersion test, (a) the result of HAp coated samples in this study, and (b) the result of uncoated samples was cited from [12]. 

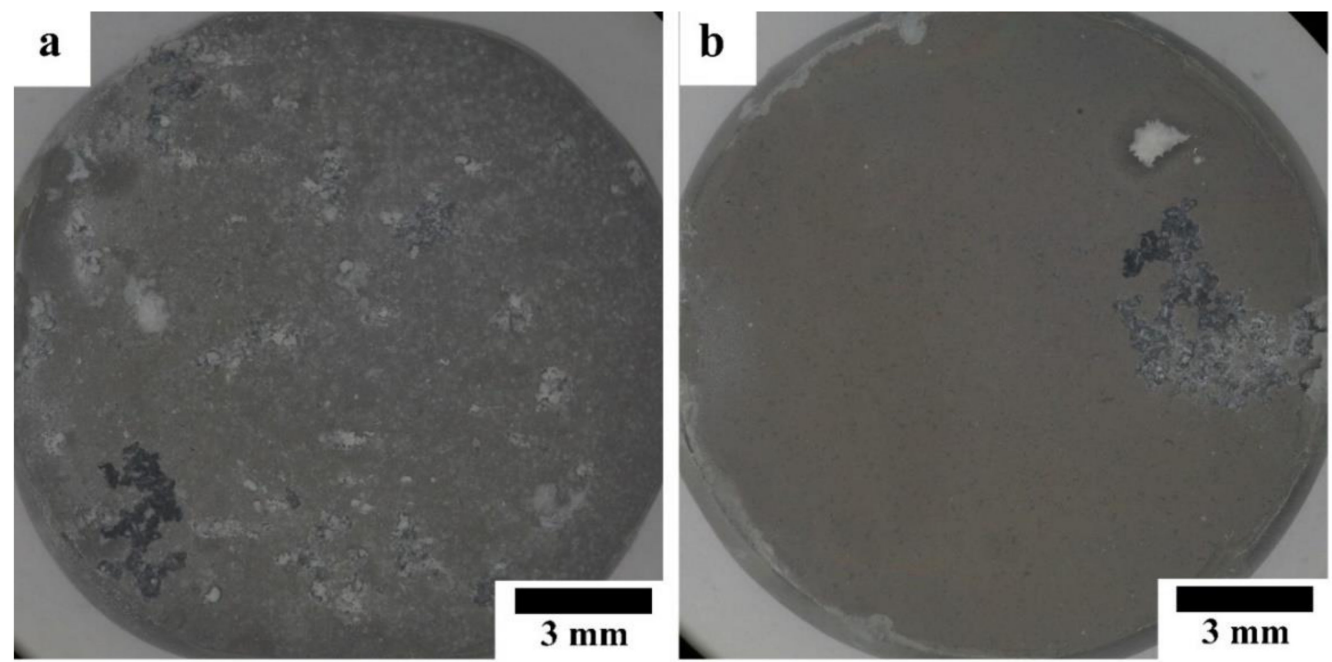

Figure 8. Morphology of HAp-coated composites after 14 days of immersion: (a) immersed HAp-coated Mg-10ZnO-10 min, (b) immersed HAp-coated Mg-10ZnO-2.5 h + 10 min.

Figure 9 shows SEM images of the non-corrosion regions of HAp-coated composites immersed in Hanks' solution. The surface of both samples was covered by corrosion product. The EDS analysis of the areas marked with yellow circles in Figure 9 is shown in Table 3. From EDS analysis results, calcium phosphate compounds were the main corrosion product. In the case of immersed HAp-coated $\mathrm{Mg}-10 \mathrm{ZnO}-2.5 \mathrm{~h}+10 \mathrm{~min}$ sample, HAp was the main constituent of the deposited calcium phosphate layer since the atomic percent ratio of $\mathrm{Ca}$ and $\mathrm{P}(\mathrm{Ca} / \mathrm{P}$ ratio $)$ was approximately 1.72 that is similar to 1.67 of HAp [19]. As for the HAp-coated Mg-10ZnO-10 min sample, amorphous calcium phosphate was presumably the main component of deposited calcium phosphate because the $\mathrm{Ca} / \mathrm{P}$ ratio was ca. 1.40 .
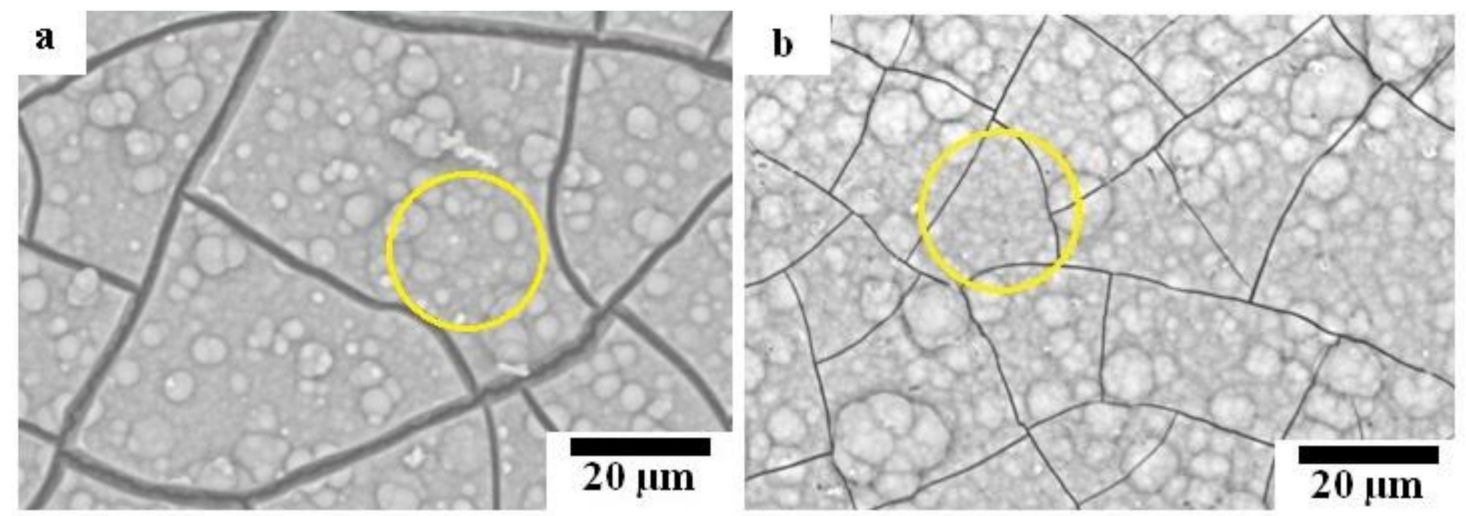

Figure 9. SEM micrographs of HAp-coated composites after 14 days of immersion: (a) immersed HAp-coated Mg-10ZnO-10 min, (b) immersed HAp-coated Mg-10ZnO-2.5 h + 10 min.

It has been reported that HAp coating improved the corrosion resistance of materials effectively as a permeation barrier against solution $[13,17,18]$. However, it has been reported that nanopores always existed in the HAp coating layer $[17,18]$, and HAp is a hydrophilic compound. Since the HAp layer on sintered pure $\mathrm{Mg}$ showed cracking along grain boundaries, defects of the HAp layer could be formed due to grain boundaries, the second phase, and the drying procedure after the coating. Therefore, the solution permeates through the HAp coating preferentially via the defects and the corrosion of the substrate initiates. Figure 10 shows an SEM image of the cross-section of the HAp-coated Mg-10ZnO-2.5 $\mathrm{h}+10 \mathrm{~min}$ sample and describes the corrosion process of the HAp-coated composites in Hanks' solution. The existence of $\mathrm{Mg}(\mathrm{OH})_{2}$ as an intermediate layer was demonstrated 
by Tomozawa et al. [17]. As can be seen, corrosion starts on the substrate via defects of the HAp coating. The corrosion of the substrate produced corrosion product at the interface of the HAp layer and the substrate. The micro galvanic corrosion due to the second phase, and grain boundaries could promote the corrosion of the substrate. The corrosion progress caused the increase in surface $\mathrm{pH}$, leading to the deposition of calcium phosphate compounds over the HAp layer. Concurrently, the corrosion progress at the interface increased the amount of corrosion product and gradually broke the dense inner layer of HAp, leading to the macroscopic localized corrosion. When the HAp layer was broken, the bare metal surface was exposed to the solution, and rapid corrosion produced a large amount of corrosion product at the corrosion sites. The formation of corrosion product filling the corrosion pits and the remaining dense HAp layer can effectively prevent severe corrosion occurring afterward.
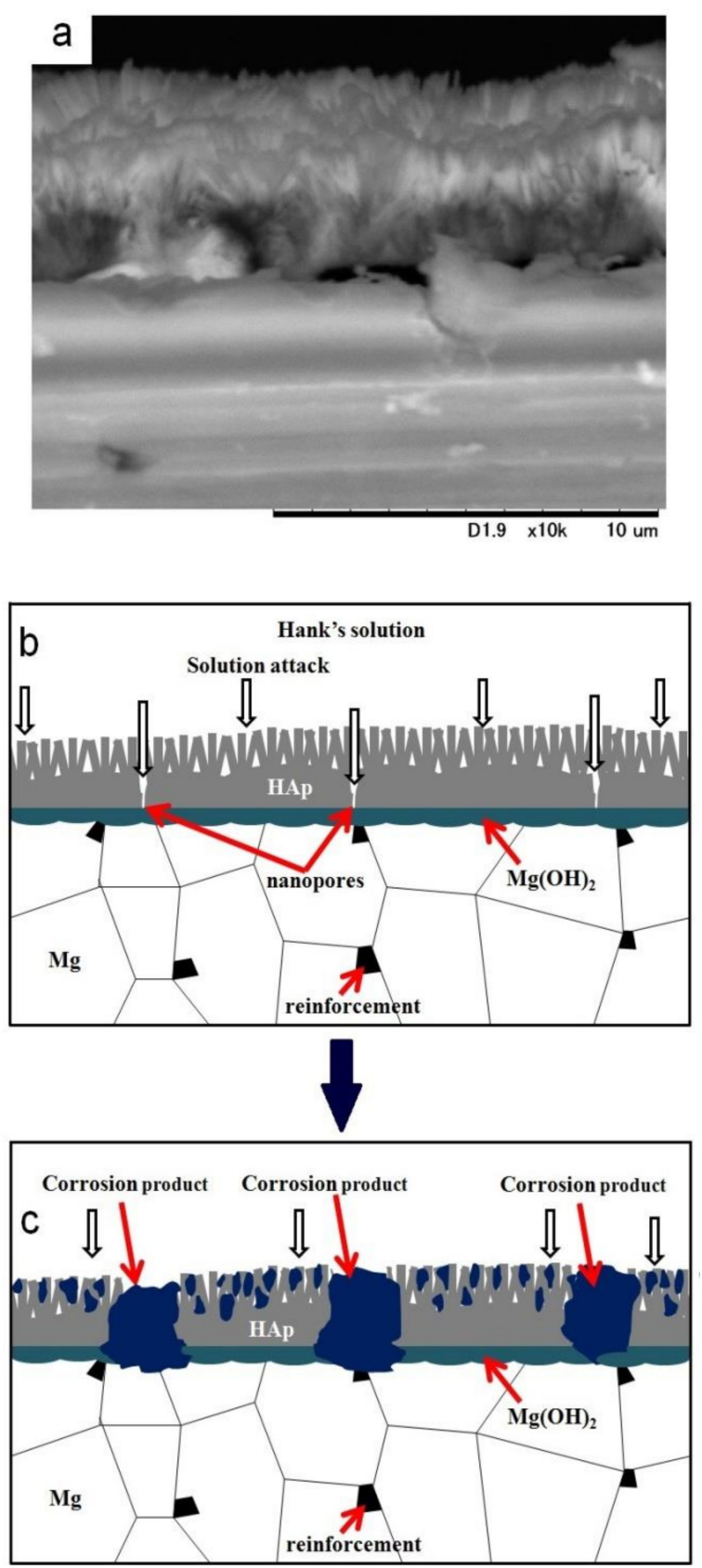

Figure 10. SEM image of the cross-section of a HAp-coated Mg-10ZnO-2.5 h + 10 min sample (a) and illustration of the corrosion process of the HAp-coated composites (b) and (c). 
Table 3. EDS analysis results on the surfaces of immersed HAp-coated composites.

\begin{tabular}{ccc}
\hline Element & $\begin{array}{c}\text { Immersed HAp-Coated } \\
\text { Mg-10ZnO-10 } \mathbf{~ m i n}\end{array}$ & $\begin{array}{c}\text { Immersed HAp-Coated } \\
\text { Mg-10ZnO-2.5 } \mathbf{~ + ~ 1 0 ~} \mathbf{~ m i n}\end{array}$ \\
\hline Oxygen (at \%) & 66.0 & 67.0 \\
\hline Calcium (at \%) & 17.5 & 19.0 \\
\hline Phosphorus (at \%) & 12.5 & 11.0 \\
\hline Magnesium (at \%) & 4.0 & 3.0 \\
\hline Ca/P ratio & 1.40 & 1.72 \\
\hline
\end{tabular}

\subsection{Polarization Tests}

Figure 11 shows the polarization curves of the HAp-coated $\mathrm{Mg}, \mathrm{Mg}-10 \mathrm{ZnO}-10 \mathrm{~min}$, and $\mathrm{Mg}-10 \mathrm{ZnO}-2.5 \mathrm{~h}+10 \mathrm{~min}$ samples in Hanks' solution. The coated Mg-10ZnO-2.5 h $+10 \mathrm{~min}$ sample exhibited the lowest corrosion current density $\left(I_{\mathrm{corr}}\right)$ and the highest corrosion potential $\left(E_{\mathrm{corr}}\right)$, while the coated $\mathrm{Mg}$ specimen showed the highest $I_{\text {corr }}$ and the lowest $E_{\text {corr. }}$. These results agreed with the results of the immersion test: the coated Mg-10ZnO- $2.5 \mathrm{~h}+10$ min exhibited the highest corrosion resistance, while the coated $\mathrm{Mg}$ showed the highest corrosion rate.

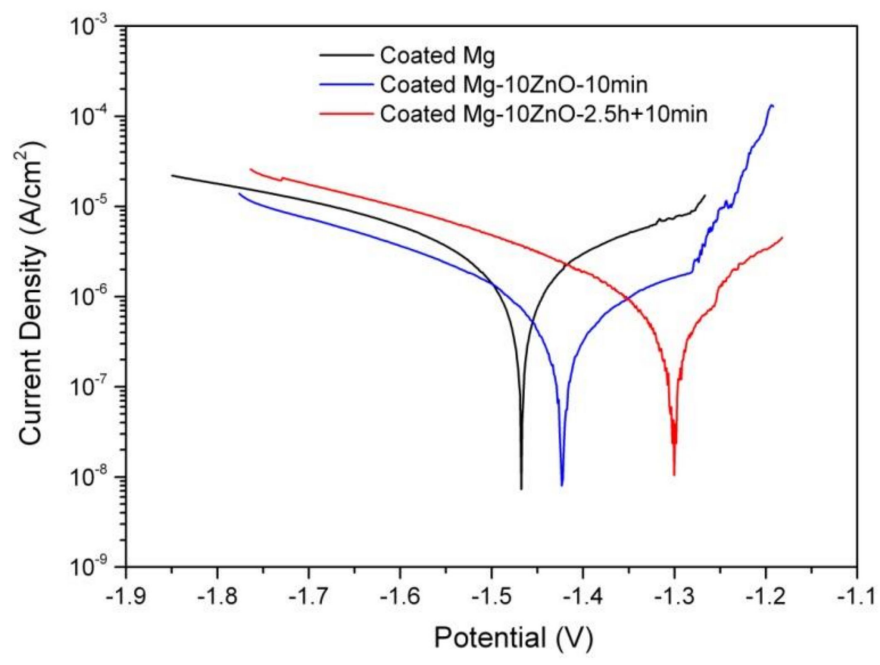

Figure 11. Potentiodynamic polarization curves of as-fabricated samples in Hanks' solution.

\subsection{Cell Viability}

Figure 12 shows the optical micrographs of the HAp-coated and uncoated samples after cell culture for 24, 48, and $72 \mathrm{~h}$. Between the samples with the same sintering condition and composition, the cell viability on the HAp-coated samples was much higher than that on uncoated samples. As for the sintered pure $\mathrm{Mg}$, no cell survived on the uncoated sample after only $24 \mathrm{~h}$. Many cells survived on the HAp-coated Mg sample after $24 \mathrm{~h}$ of culture even though some localized corrosion occurred. However, after $48 \mathrm{~h}$, corrosion occurred over almost the entire surface of the HAp-coated Mg sample, and corrosion product covered the whole surface. No cell remained on this sample. After $72 \mathrm{~h}$, the HAp-coated Mg sample was corroded more severely, and a thick layer of corrosion product covered the entire surface of this sample.

On the uncoated Mg-10ZnO-10 min and Mg-10ZnO-2.5 $\mathrm{h}+10 \mathrm{~min}$ composites, a part of the cells survived for 24 and $48 \mathrm{~h}$, respectively. After $48 \mathrm{~h}$, on the uncoated $\mathrm{Mg}-10 \mathrm{ZnO}-10 \mathrm{~min}$, corrosion product almost covered the surface, and no cells remained. After $72 \mathrm{~h}$ on the uncoated Mg-10ZnO-2.5 $\mathrm{h}+10 \mathrm{~min}$, significant corrosion product was not observed, while the number of cells decreased. Both HAp-coated $\mathrm{Mg}-10 \mathrm{ZnO}-10 \mathrm{~min}$ and $\mathrm{Mg}-10 \mathrm{ZnO}-2.5 \mathrm{~h}+10 \mathrm{~min}$ samples showed very good cell viability. No obvious 
corrosion was observed on both HAp-coated composites after $72 \mathrm{~h}$. These facts indicate that HAp coating is very effective in improving the corrosion resistance of the as-fabricated composites, resulting in the significant improvement of cell viability on the composites. The cell density on both composites increased gradually with an increase in cell culture time, suggesting the good biocompatibility of the HAp-coated surfaces. As for the comparison between two composites, cell density on the HAp-coated Mg-10ZnO-2.5 h + 10 min sample was higher than that on the HAp-coated Mg-10ZnO-10 min sample.

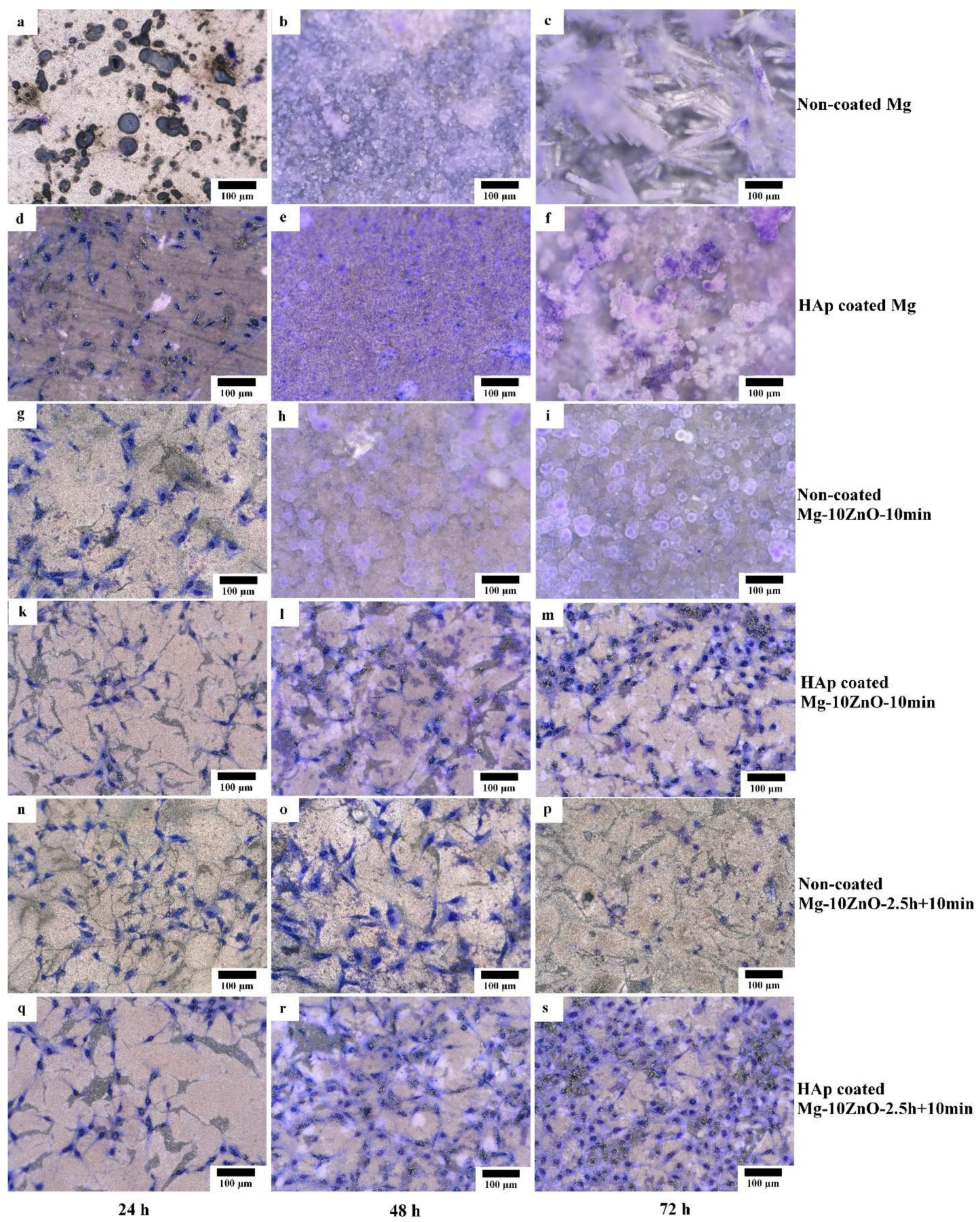

Figure 12. Morphology of the coated and uncoated samples after cell culture test for 24, 48, and $72 \mathrm{~h}$, respectively. $(\mathbf{a}, \mathbf{b}, \mathbf{c})$ uncoated $\mathrm{Mg}$, (d,e,f) HAp coated $\mathrm{Mg}$, (g,h, $\mathbf{i})$ uncoated $\mathrm{Mg}-10 \mathrm{ZnO}-10 \mathrm{~min}$, $(\mathbf{k}, \mathbf{l}, \mathbf{m})$ HAp coated Mg-10ZnO-10min, $(\mathbf{n}, \mathbf{o}, \mathbf{p})$ uncoated Mg-10ZnO-2.5h+10min, $(\mathbf{q}, \mathbf{r}, \mathbf{s})$ HAp coated Mg-10ZnO-2.5h+10min. 
As demonstrated in previous studies, HAp improves the biocompatibility and bioactivity of the materials $[20,24,25]$. The formation of HAp coating is not only for reducing the corrosion rate of the substrate but also for promoting new bone growth $[20,25,26]$. In this study, Figure 12 shows that osteoblast cells can grow well on the whole surface of the HAp-coated composites.

Figure 13 shows optical micrographs of the uncoated $\mathrm{Mg}-10 \mathrm{ZnO}-2.5 \mathrm{~h}+10 \mathrm{~min}$ sample after $24 \mathrm{~h}$ of cell culture. Some local corrosion occurred on the surface of the uncoated sample. High magnification images show that almost no cell survived in the corroded region (Figure 13b), and cells extended well on the non-corroded region (Figure 13c). This result is consistent with the previous studies, which revealed that the corrosion rate of $\mathrm{Mg}$ alloys strongly influenced the cell viability [6,25-28]. When the sample was immersed in the cell culture medium, local corrosion occurred immediately, and hydrogen gas evolution with a high rate was observed. The hydrogen gas evolution at a high rate prevented a part of cells from adhering to the surface of the sample $[6,27,28]$. Song postulated that the hydrogen gas evolution rate of $0.01 \mathrm{~mL} / \mathrm{cm}^{2} /$ day is a tolerated rate for cell proliferation [27]. In addition, a part of cells once adhered to the surface but detached due to the occurrence of corrosion around the cells. In this work, the HAp coating layer effectively prevented the hydrogen gas evolution at the initial time of cell culture. Therefore, cells adhered well to the surface of the HAp-coated sample. Figure 14 shows that corrosion product deposited on the surface of HAp-coated Mg-10ZnO-2.5 h $+10 \mathrm{~min}$ after $72 \mathrm{~h}$ of cell culture. However, cells can proliferate over and around the corrosion product. The HAp coating retarded the corrosion ( $\mathrm{pH}$ increase and hydrogen gas evolution) at a certain tolerable level for cells, allowing cells to proliferate until $72 \mathrm{~h}$ even on the corrosion product. These results demonstrated that the retardation of corrosion is very important for cell viability, and HAp coating is an effective method for improving cell viability on $\mathrm{Mg}$ matrix composites.

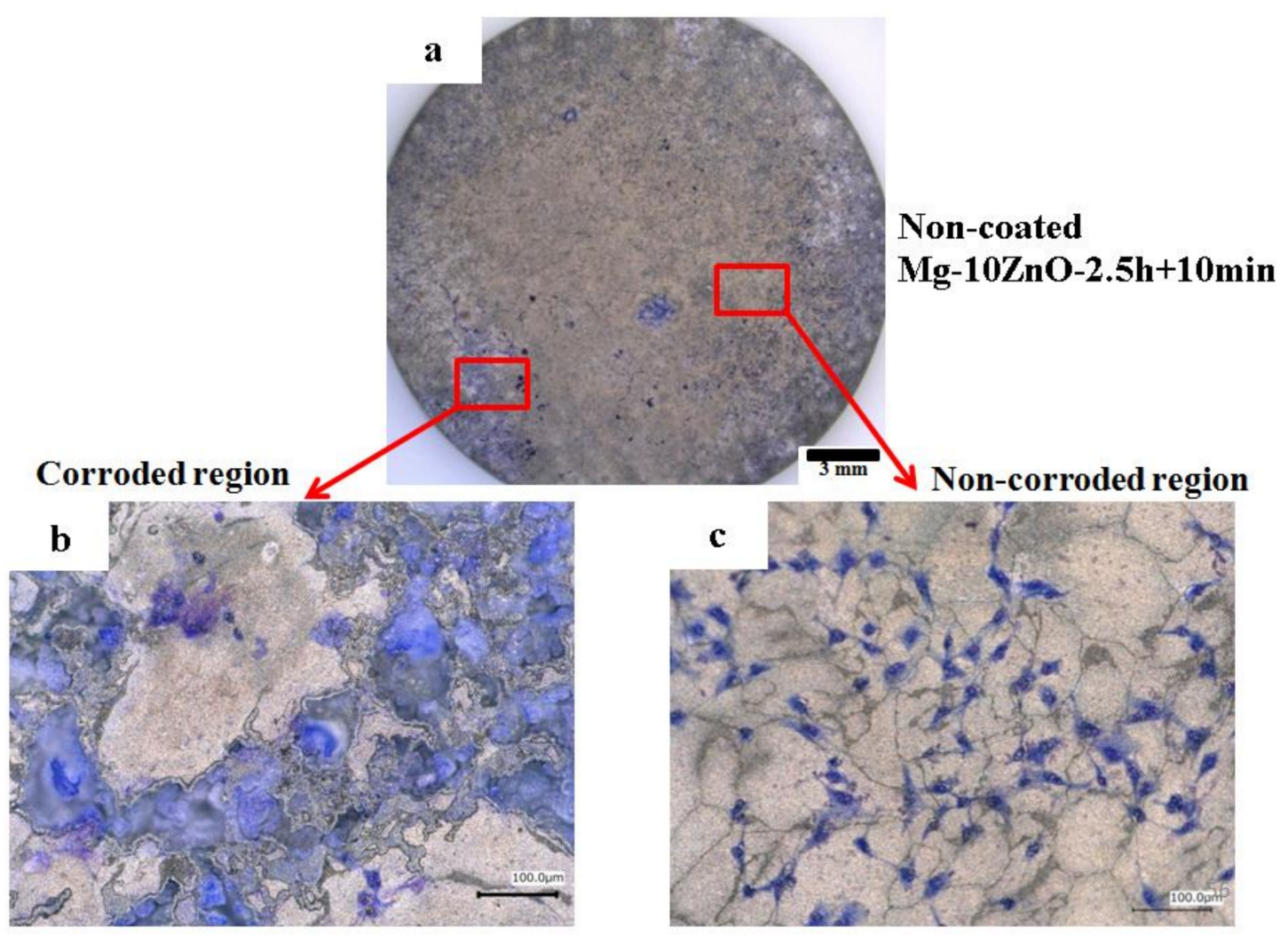

Figure 13. Morphology of the uncoated Mg-10ZnO-2.5 $\mathrm{h}+10$ min sample after $24 \mathrm{~h}$ of cell culture, (a) full surface image, (b) corroded region, (c) non-corroded region. 


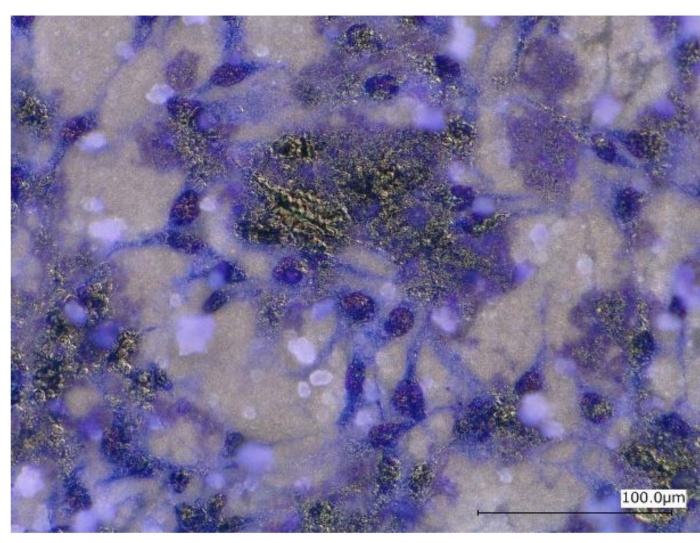

Figure 14. Morphology of the HAp-coated Mg-10ZnO-2.5 h + 10 min sample after $72 \mathrm{~h}$ of cell culture.

\section{Conclusions}

HAp coating layer was formed successfully on the sintered $\mathrm{Mg}-\mathrm{ZnO}$ in situ composites with different sintering conditions by a chemical solution treatment. The HAp layer effectively improved the corrosion resistance and the cell viability on the surface of the composites regardless of the sintering condition. The HAp-coated $\mathrm{Mg}-\mathrm{ZnO}$ composite with longer total sintering time showed higher corrosion resistance and cell viability than those with shorter sintering time. The HAp coating layer effectively retarded the corrosion enough to improve the cell viability on the surface of the composites, although the corrosion resistance of HAp-coated composite depended on the corrosion resistance of uncoated composites. The results suggested that HAp-coated Mg matrix in situ composites are promising materials for biodegradable implant applications.

Author Contributions: N.Q.C. contributed to this work in experiment planning, experiment measurements, data analysis and manuscript preparation. H.M.L. contributed in result analysis and evaluation, manuscript preparation. K.M.P. and N.V.N. contributed in result analysis and evaluation. S.H. contributed in experiment measurements, data analysis, and manuscript preparation. E.K. contributed in experiment planning, experiment measurements, data analysis, and manuscript preparation.

Funding: This research was funded by Vietnam National Foundation for Science and Technology Development (NAFOSTED) under grant number 103.02-2018.56, and the APC was funded by Tokyo Institute of Technology.

Acknowledgments: The authors would like to thank Japan Light Metal Foundation and the Molecule \& Material Synthesis Platform, National Institute for Materials Science (NIMS-Japan) for supporting a part of research expense and facility. The authors also sincerely thank Naomi Noda for her help during the cell culture test.

Conflicts of Interest: There is no conflict of interest.

\section{References}

1. Wu, G.; Ibrahim, J.M.; Chu, P.K. Surface design of biodegradable magnesium alloys-A review. Surf. Coat. Technol. 2013, 233, 2-12. [CrossRef]

2. Li, L.Y.; Cui, L.Y.; Zeng, R.C.; Li, S.Q.; Chen, X.B.; Zheng, Y.; Kannan, M.B. Advances in functionalized polymer coatings on biodegradable magnesium alloys-A review. Acta Biomater. 2018, 79, 23-36. [CrossRef] [PubMed]

3. Agarwal, S.; Curtin, J.; Duffy, B.; Jaiswal, S. Biodegradable magnesium alloys for orthopaedic applications: A review on corrosion, biocompatibility and surface modifications. Mater. Sci. Eng. C 2016, 68, 948-963. [CrossRef] [PubMed]

4. Staiger, M.P.; Pietak, A.M.; Huadmai, J.; Dias, G. Magnesium and its alloys as orthopedic biomaterials: A review. Biomaterials 2006, 27, 1728-1734. [CrossRef]

5. Jahnen-Dechent, W.; Ketteler, M. Magnesium basics. CKJ Clin. Kidney J. 2012, 5. [CrossRef]

6. Witte, F.; Kaese, V.; Haferkamp, H.; Switzer, E.; Meyer-Lindenberg, A.; Wirth, C.J.; Windhagen, H. In vivo corrosion of four magnesium alloys and the associated bone response. Biomaterials 2005, 26, 3557-3563. [CrossRef] 
7. Kirkland, N.T.; Lespagnol, J.; Birbilis, N.; Staiger, M.P. A survey of bio-corrosion rates of magnesium alloys. Corros. Sci. 2010, 52, 287-291. [CrossRef]

8. Dubey, A.; Jaiswal, S.; Lahiri, D. Mechanical Integrity of Biodegradable Mg-HA Composite During In Vitro Exposure. J. Mater. Eng. Perform. 2019. [CrossRef]

9. Witte, F.; Feyerabend, F.; Maier, P.; Fischer, J.; Sto“ rmer, M.; Blawert, C.; Dietzel, W.; Hortb, N. Biodegradable magnesium-hydroxyapatite metal matrix composites. Biomaterials 2007, 28, 2163-2174. [CrossRef]

10. Narita, K.; Tian, Q.; Johnson, I.; Zhang, C.; Kobayashi, E.; Liu, H. Degradation behaviors and cytocompatibility of $\mathrm{Mg} / \beta$-tricalcium phosphate composites produced by spark plasma sintering. J. Biomed. Mater. Res. Part $B$ Appl. Biomater. 2019. [CrossRef]

11. Cao, N.Q.; Narita, K.; Kobayashi, E.; Sato, T. Evolution of the microstructure and mechanical properties of Mg-matrix in situ composites during spark plasma sintering. Powder Metall. 2016, 59, 302-307. [CrossRef]

12. Cao, N.Q.; Pham, D.N.; Kai, N.; Dinh, H.V.; Hiromoto, S.; Kobayashi, E. In Vitro Corrosion Properties of Mg Matrix In Situ Composites Fabricated by Spark Plasma Sintering. Metals 2017, 7, 358. [CrossRef]

13. Hiromoto, S.; Tomozawa, M. Hydroxyapatite coating of AZ31 magnesium alloy by a solution treatment and its corrosion behavior in $\mathrm{NaCl}$ solution. Surf. Coatings Technol. 2011, 205, 4711-4719. [CrossRef]

14. Tang, H.; Xin, T.Z.; Luo, Y.; Wang, F.P. In vitro degradation of AZ31 magnesium alloy coated with hydroxyapatite by sol-gel method. Mater. Sci. Technol. 2013, 29, 547-552. [CrossRef]

15. Kaabi Falahieh Asl, S.; Nemeth, S.; Tan, M.J. Improved corrosion protection of magnesium by hydrothermally deposited biodegradable calcium phosphate coating. Mater. Chem. Phys. 2015, 161, 185-193. [CrossRef]

16. Kim, S.Y.; Kim, Y.K.; Ryu, M.H.; Bae, T.S.; Lee, M.H. Corrosion resistance and bioactivity enhancement of MAO coated Mg alloy depending on the time of hydrothermal treatment in Ca-EDTA solution. Sci. Rep. 2017, 7, 1-11. [CrossRef]

17. Tomozawa, M.; Hiromoto, S. Growth mechanism of hydroxyapatite-coatings formed on pure magnesium and corrosion behavior of the coated magnesium. Appl. Surf. Sci. 2011, 257, 8253-8257. [CrossRef]

18. Yang, H.; Xia, K.; Wang, T.; Niu, J.; Song, Y.; Xiong, Z.; Zheng, K.; Wei, S.; Lu, W. Growth, in vitro biodegradation and cytocompatibility properties of nano-hydroxyapatite coatings on biodegradable magnesium alloys. J. Alloys Compd. 2016, 672, 366-373. [CrossRef]

19. Kuwahara, H.; Al-Abdullat, Y.; Mazaki, N.; Tsutsumi, S.; Aizawa, T. Precipitation of Magnesium Apatite on Pure Magnesium Surface during Immersing in Hank's Solution. Mater Trans. 2001, 42, 1317-1321. [CrossRef]

20. Hiromoto, S.; Shishido, T.; Yamamoto, A.; Maruyama, N.; Somekawa, H.; Mukai, T. Precipitation control of calcium phosphate on pure magnesium by anodization. Corros. Sci. 2008, 50, 2906-2913. [CrossRef]

21. Mann, C.K.; Yoe, J.H. Spectrophotometric Determination of Magnesium with Sodium 1-Azo-2-hydroxy-3(2,4-dimethylcarboxanilido)-naphthalene-1'-(2-hydroxybenzene-5-sulfonate). Anal. Chem. 1956, 28, 202-205.

22. Watanabe, H.; Tanaka, H. Dual-wavelength spectrophotometric determination of magnesium with xylidyl blue I and nonionic surfactant. Bunseki Kagaku. 1977, 26, 635-639. [CrossRef]

23. Baker, H. ASM Handbook; American Society for Metals: Metals Park, OH, USA, 1992; Volume 3, pp. 2-285.

24. Husak, Y.; Solodovnyk, O.; Yanovska, A.; Kozik, Y.; Liubchak, I.; Ivchenko, V.; Mishchenko, O.; Zinchenko, Y.; Kuznetsov, V.; Pogorielov, M. Degradation and In Vivo Response of Hydroxyapatite-Coated Mg Alloy. Coatings 2018, 8, 375. [CrossRef]

25. Hiromoto, S.; Inoue, M.; Taguchi, T.; Yamane, M.; Ohtsu, N. In vitro and in vivo biocompatibility and corrosion behaviour of a bioabsorbable magnesium alloy coated with octacalcium phosphate and hydroxyapatite. Acta Biomater. 2015, 11, 520-530. [CrossRef]

26. Noviana, D.; Paramitha, D.; Ulum, M.F.; Hermawan, H. The effect of hydrogen gas evolution of magnesium implant on the postimplantation mortality of rats. J. Orthop. Transl. 2016, 5, 9-15. [CrossRef]

27. Song, G. Control of biodegradation of biocompatable magnesium alloys. Corros. Sci. 2007, 49, $1696-1701$. [CrossRef]

28. Shadanbaz, S.; Dias, G.J. Calcium phosphate coatings on magnesium alloys for biomedical applications: A review. Acta Biomater. 2012, 8, 20-30. [CrossRef]

(C) 2019 by the authors. Licensee MDPI, Basel, Switzerland. This article is an open access article distributed under the terms and conditions of the Creative Commons Attribution (CC BY) license (http://creativecommons.org/licenses/by/4.0/). 